ISSN: 2224-0616

Int. J. Agril. Res. Innov. Tech. 11(1): 84-91, June 2021

DOI: https://doi.org/10.3329/ijarit.v11i1.54470
OPEN 2 ACCESS

Available online at https://ijarit.webs.com https://www.banglajol.info/index.php/IJARIT

\title{
Comparative profitability analysis and resource use efficiency of beekeeping using wooden and poly hive in some selected areas of Bangladesh
}

\author{
F.T. Sadia ${ }^{1 *}$, M.S. Hossain ${ }^{2}$, R. Begum ${ }^{1}$ and M.H.K. Sujan ${ }^{3}$
}

Received 27 April 2021, Revised 16 June 2021, Accepted 23 June 2021, Published online 30 June 2021

\begin{abstract}
A B S T R A C T
Apiarist traditionally adopt wooden hive in beekeeping. Modern poly hive provides a superior environment to raise and keep the honeybee population more vigorous due to its high-tech internal facilities and sanitary system. This study was conducted to examine the comparative profitability and resource use efficiency of beekeeping using traditional wooden hive and modern poly hive in Bangladesh during 2017-18. A total of 60 beekeepers, all have traditional wooden hive and 15 have modern poly hive, were randomly selected from Sirajganj, Gazipur and Satkhira districts to conduct farm level survey with pre-tested questionnaire. Findings of the study reveal that per hive gross and net return were Tk. 11019.26 and 4082.45 for wooden hive and Tk. 27373.34 and 19838.42 for poly hive, respectively. Total cost of beekeeping was Tk. 6936.81 and 7534.92 per hive for wooden and poly hive, respectively. Besides, benefit-cost ratios (BCR) were 1.59 and 3.63 for wooden and poly hive, respectively. Cobb-Douglas production function analysis reveals that labour, transportation, insecticide, equipment, hive and rental costs had significant influence on the returns of beekeeping. More than two times higher BCR and significant positive dummy variable "modern poly hive" indicate the greater profitability of beekeeping in modern poly hives. Resource use efficiency analysis indicates that labour, insecticide, equipment, and honey extraction inputs were under-utilized while feed, transportation, marketing, hive, colony and rental inputs were over-utilized. Beekeeping is also affected by some constraints including high costs of modern poly hive accessories, lack of skilled labour and initial capital, inadequate transportation and marketing facilities. Government and other related organizations should take necessary measures to mitigate those problems. Based on the findings, it is recommended to adopt modern poly hive in beekeeping.
\end{abstract}

Keywords: Apiary, Cobb-Douglas production function, Constraints, Honeybee, Profitability, Resource use efficiency.

\footnotetext{
${ }^{1}$ Dept. of Agricultural Economics, Sher-e-Bangla Agricultural University, Dhaka 1207, Bangladesh.

${ }^{2}$ Dept. of Entomology, Sher-e-Bangla Agricultural University, Dhaka 1207, Bangladesh.

${ }^{3}$ Dept. of Development and Poverty Studies, Sher-e-Bangla Agricultural University, Dhaka 1207, Bangladesh.

*Corresponding author's email: fatematussadia92@gmail.com (F.T. Sadia)
}

Cite this article as: Sadia, F.T., Hossain, M.S., Begum, R. and Sujan, M.H.K. 2021. Comparative profitability analysis and resource use efficiency of beekeeping using wooden and poly hive in some selected areas of Bangladesh. Int. J. Agril. Res. Innov. Tech. 11(1): 84-91. https://doi.org/10.3329/ijarit.v11i1.54470

\section{Introduction}

Beekeeping is an economically sustainable occupation, offering attractive opportunities for self-employment with multiple benefits (Moniruzzaman and Rahman, 2009; Adgaba et al., 2014; Vaziritabar and Esmaeilzade, 2016). It requires small investment and shorter duration but promises a high return in comparison to other income generating activities. Most valuable return of this industry is the honey, wax and pollination service rendered by bees, which increase yield of many agricultural and horticultural crops without changing environmental balance (Adgaba et al., 2014; Klatt et al., 2014; Veer and Jitender, 2017). Beekeeping is feasible across the country on the basis of existing natural bee plants in Bangladesh where Apis cerana indica and Apis mellifera are treated as commercially important honeybee species (Kumsa and Takele, 2014; Islam et al., 2016). Presently, the honey farming is gaining popularity among a section of young farmers in different districts of Bangladesh including Sirajganj, Gajipur, Tangail, Sunderban and hill tracts area. Participation of rural women and youth in beekeeping also provide a unique opportunity to improve rural livelihood and poverty reduction (Ayansola and Davies, 2012; Famuyide et al., 2014; Vaziritabar and Esmaeilzade, 2016). In Bangladesh, around 6000 tons of honey was produced in 2017 of which 
500-700 tons were exported to India. With some interventions, this production can be enhanced up to 1-1.5 million tons per year (Abdullah, 2019). Thus, beekeeping has a great scope in broadening its base in Bangladesh. The country possesses enormous potential to transform beekeeping into a productive industry.

The most important tool for commercial beekeeping is the artificial boxes known as Beehive. A beehive is an enclosed, man-made structure to house a honeybee nest, in which some honeybee species live and raise their young. Numerous hive designs are available in Bangladesh, but beekeepers usually use wooden Langstroth hives (Fazlullah, 2018). In these traditional single wooden boxes, broods of honeybee and honey remain in same box, and during honey harvest broods are damaged which is unhygienic and harmful. Bee management in wooden boxes also encourages pest and diseases of honeybee. Recently, a new category of hive made of high quality polystyrene (poly hive) has been gaining popularity among beekeepers in different countries including Bangladesh. This poly hive was first introduced in Europe in 1970 s and Krishi Gobeshona Foundation (KGF) brought it in Bangladesh in 2016. It provides superior insolation benefits for the bees, helping them keep warm in the colder months and cooler in the hotter months. This tends to show better overwintering rates and more honey production during the summer. Thus, bees produce larger amount of honey in poly hives than the others do (Kiros and Tsegay, 2017; Hossain et al., 2019). Besides, pollen, propolis, wax, royal jelly, bee venom etc. can be extracted from poly hives, which are totally impossible in case of traditional wooden hives. Artificial feeding of bees is also easier in poly hives. Using traditional wooden hives beekeepers can harvest maximum 36-38 kg of inferior quality honey containing $24-26 \%$ or more moisture whereas from poly hive they can harvest nearly $100 \mathrm{~kg}$ of superior quality honeys containing 20-21\% moisture (Hossain, 2017). Poly hive also enables beekeepers to collect at least $0.5 \mathrm{~kg}$ pollen from each box per year, which is enriched with vitamin $\mathrm{B}$ and can be taken by human as vitamin supplement. It has opened up an opportunity to collect nearly 25 metric ton pollen in Bangladesh. In this box, possibility of disease infestation is very low and apiarist can be benefitted from it for more than 30 years (Hossain, 2017).

Although Moniruzzaman and Rahman (2009), Abdullahi et al. (2014), Getachew et al. (2015), Islam et al. (2016), Vaziritabar and Esmaeilzade (2016) and Al-Ghamdi et al. (2017) conducted studies on economic performance of beekeeping around the world, to date, no adequate comparative study has been conducted on the profitability and resource use efficiency of wooden hive and poly hive in this region. The purpose of this study is to contribute in this specific gap of the literature. This study will help the researchers, academicians, policy makers, extension and development workers as well as the beekeepers to know the huge potentiality of commercial beekeeping using modern poly hive and the pros and cons of beekeeping in Bangladesh.

\section{Methodology}

\section{Study areas and data sources}

This study was conducted in Sirajganj, Gazipur and Satkhira districts of Bangladesh (Fig. 1). These districts were selected based on the high concentration of bee forages and the availability of beekeepers in blooming seasons. A total of 60 beekeepers from these three districts were selected by applying simple random sampling technique. All the 60 beekeepers had traditional wooden hive and 15 of them had modern poly hive. Primary data were collected from Sirajganj district at the flowering stage of mustard, from Gazipur district at the blooming period of litchi and from Satkhira district at the blooming season of sundarban mangrove plants. Thus, the field survey was conducted with a structured and pretested questionnaire from $1^{\text {st }}$ November 2017 to $30^{\text {th }}$ May 2018. Before finalizing the questionnaire, personal observations and personal interviews with beekeepers, extension workers and honey-bee experts were also done. By conducting face-to-face interview, data were collected on input use pattern, annual yield per hive, input and output prices and constraints faced by beekeepers during their honey production, etc. Besides, secondary data were collected from different sources such as books, research articles, periodicals, office reports, organizations like BSCIC, Proshika, etc. 


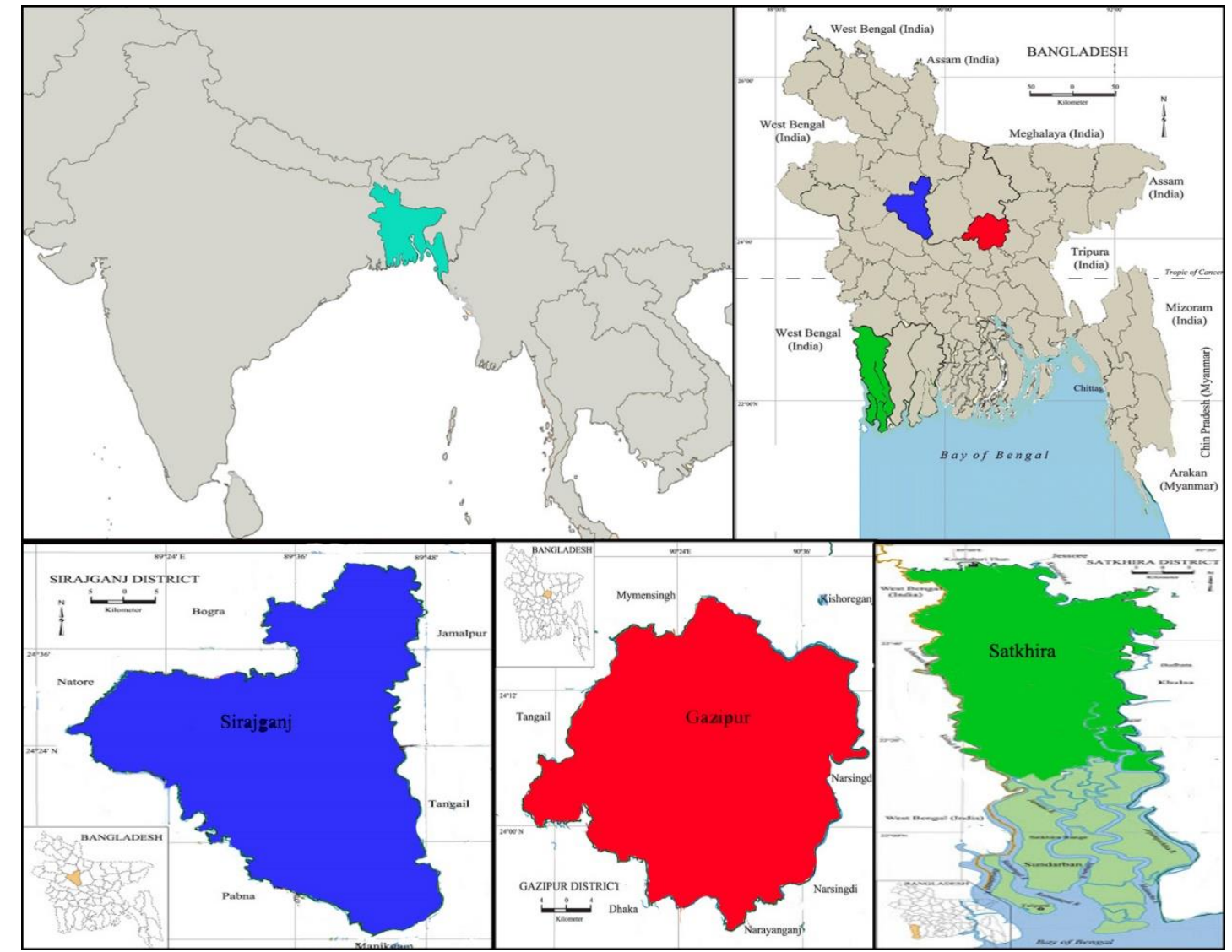

Fig. 1. Map of the study areas.

\section{Analytical techniques}

Collected primary data were analyzed by using both descriptive and inferential statistics. Descriptive statistics like mean and percentage were used to investigate the use of different inputs on honey production by the beekeepers. Profitability of beekeeping was estimated by using following formula (as used by Sujan et al., 2017a \& b):

$\mathrm{GR}_{\mathrm{i}}=\sum_{\mathrm{i}=1}^{\mathrm{n}} \mathrm{Q}_{\mathrm{ij}} \mathrm{P}_{\mathrm{ij}}$

Where, $\mathrm{GR}_{\mathrm{i}}=$ Gross return of $\mathrm{i}^{\text {th }}$ beekeeper; $\mathrm{Q}_{\mathrm{ij}}=$ Quantity of $j^{\text {th }}$ product of $i^{\text {th }}$ beekeeper; $P_{i j}=$ Price of $j^{\text {th }}$ product of $i^{\text {th }}$ beekeeper; $i=1,2,3 \ldots \ldots \ldots n$.

Net return was calculated by deducting all costs from the gross return. To estimate the net return of beekeeping following formula was used:

$\pi_{\mathrm{i}}=\mathrm{GR}_{\mathrm{i}}-\sum_{\mathrm{i}=1}^{\mathrm{n}} \mathrm{P}_{\mathrm{ij}} \mathrm{X}_{\mathrm{ij}}-\mathrm{TFC}_{\mathrm{i}}$

Where, $\pi_{i}=$ Net return of $i^{\text {th }}$ beekeeper; $\mathrm{GR}_{\mathrm{i}}=$ Gross return of $i^{\text {th }}$ beekeeper; $P_{i j}=$ Price of $j^{\text {th }}$ input used by $i^{\text {th }}$ beekeeper; $X_{i j}=$ Quantity of $j^{\text {th }}$ input used by $\mathrm{i}^{\text {th }}$ beekeeper; $\mathrm{TFC}_{\mathrm{i}}=$ Total fixed costs of $i^{\text {th }}$ beekeeper; $i=1,2,3, \ldots \ldots . n$.
Inferential statistics was applied to explore the factors affecting the gross returns of beekeeping. Cobb-Douglas production function was employed to estimate the influence of the factors of beekeeping. This function was used because of its mathematical properties and ease of interpretation. It is also relatively easy to estimate because in logarithmic form it is linear and parsimonious (Beattie and Taylor, 1985). The functional form of the Cobb-Douglas production function was as follows:

$\mathrm{Y}=\mathrm{AX}_{1}{ }^{\beta 1} \mathrm{X}_{2}{ }^{\beta 2}$----------------- $\mathrm{X}_{\mathrm{n}}{ }^{\beta n} \mathrm{e}^{\mathrm{ui}}$

The empirical production function for this study was the following:

$\ln \mathrm{Y}=\alpha+\beta_{1} \ln \mathrm{X}_{1}+\beta_{2} \ln \mathrm{X}_{2}+\beta_{3} \ln \mathrm{X}_{3}+\beta_{4} \ln \mathrm{X}_{4}+\beta_{5}$ $\ln X_{5}+\beta_{6} \ln X_{6}+\beta_{7} \ln X_{7}+\beta_{8} \ln X_{8}+\beta_{9} \ln X_{9}+\beta_{10}$ $\ln \mathrm{X}_{10}+\beta_{11} \mathrm{D}+\mathrm{U}_{\mathrm{i}}$

Where, $\mathrm{Y}=$ Gross return (Tk. hive $\left.\mathrm{e}^{-1}\right) ; \mathrm{X}_{1}=$ Labour cost $\left(\right.$ Tk. hive $\left.{ }^{-1}\right) ; \mathrm{X}_{2}=$ Feed cost $\left(\right.$ Tk. hive $\left.{ }^{-1}\right) ; \mathrm{X}_{3}=$ Transportation cost (Tk. hive-1); $\mathrm{X}_{4}=$ Insecticide cost (Tk. hive-1); $\mathrm{X}_{5}=$ Equipment cost $\left(\right.$ Tk. hive $\left.{ }^{-1}\right)$; $\mathrm{X}_{6}=$ Marketing cost $\left(\right.$ Tk. hive $\left.{ }^{-1}\right) ; \mathrm{X}_{7}=$ Hive cost (Tk. hive $\left.{ }^{-1}\right) ; \mathrm{X}_{8}=$ Colony cost (Tk. hive $\left.{ }^{-1}\right) ; \mathrm{X}_{9}=$ Rental cost (Tk. hive $\left.{ }^{-1}\right) ; \mathrm{X}_{10}=$ Honey extraction cost (Tk. hive $\left.{ }^{-1}\right) ; \mathrm{D}=$ Dummy variable (1 for poly hive; o for otherwise); $\alpha=$ Intercept; $\beta_{1}, \beta_{2}$---- $\beta_{11}$ $=$ Coefficients of the respective variables to be estimated; and $\mathrm{U}_{\mathrm{i}}=$ Error term . 
In order to investigate the resource use efficiency (RUE) of beekeeping, the ratio of marginal value product (MVP) to the marginal factor cost (MFC) for each input was computed and tested for its equality to 1 (as used by Sujan et al., 2021).

$\mathrm{RUE}=\frac{\mathrm{MVP}}{\mathrm{MFC}}$

Where, RUE $>1$, RUE $<1$ and RUE $=1$ corresponds with the under-utilization, overutilization and optimal utilization of resources, respectively.

The MVP was estimated as follows:

$\operatorname{MVP}\left(\mathrm{X}_{\mathrm{i}}\right)=\beta_{\mathrm{i}} \frac{\overline{\mathrm{Y}}(\mathrm{GM})}{\overline{\mathrm{X}}_{\mathrm{i}}(\mathrm{GM})}$

Where, $\bar{Y}(\mathrm{GM})=$ geometric mean of gross return in Tk.; $\bar{X}_{i}(\mathrm{GM})=$ geometric mean of $i^{\text {th }}$ variable inputs in Tk.; $\beta i=$ coefficient of parameters; $i=1$, $2, \ldots \ldots \ldots \mathrm{n}$.

MFC represents the price of input per unit. The MFCs of all the inputs were expressed in terms of an additional taka in calculating the ratio of MVP to MFC. Thus, MFC was equal to 1 and the ratio was equal to their respective MVPs.

To identify the constraints faced in beekeeping, open-ended questions regarding the problems of beekeeping were asked to the respondents. Identified constraints were ranked based on their frequencies.

Table 1 . Yearly per hive cost of beekeeping.

\section{Results and Discussion}

\section{Comparative profitability of beekeeping in traditional wooden and modern poly hive}

Profitability is a major criterion to make decision for beekeeping at commercial level. It can be measured based on net return, gross margin and ratio of return to total cost. The costs of all items were calculated to identify the total cost of production. The returns from beekeeping have been estimated based on the value of main products and by-products.

\section{Comparative cost of beekeeping}

For calculating the total cost of beekeeping, all the variable cost like cost of labour, feed, transportation, marketing, insecticide, tools and equipment, honey extraction and all the fixed cost like cost of hive, colony, rental value and interest on operating capital were considered (Table 1). Results of the study indicates that yearly per hive total cost of production were Tk. 6936.81 and Tk. 7534.92 for traditional wooden and modern poly hive, respectively. In case of Modern poly hive, both fixed and variable costs were higher as the higher total cost. Total variable costs were 34.00 and $35.00 \%$ for beekeeping in traditional wooden and modern poly hive, respectively. Among the other variable inputs, feed, labour and transportation costs were major contributors.

\begin{tabular}{|c|c|c|c|c|c|}
\hline \multirow{2}{*}{$\begin{array}{l}\text { Sl. } \\
\text { No. }\end{array}$} & \multirow[t]{2}{*}{ Cost items } & \multicolumn{2}{|c|}{ Wooden hive } & \multicolumn{2}{|c|}{ Modern poly hive } \\
\hline & & Cost (Tk.) & $\begin{array}{l}\text { Percent of } \\
\text { total cost }\end{array}$ & Cost (Tk.) & $\begin{array}{l}\text { Percent of } \\
\text { total cost }\end{array}$ \\
\hline \multirow[t]{7}{*}{ A. } & Labour cost & $615 \cdot 53$ & 8.87 & 499.80 & 6.63 \\
\hline & Feed cost & 1347.73 & 19.43 & 1764.00 & 23.41 \\
\hline & Transportation cost & 204.04 & 2.94 & 205.83 & 2.73 \\
\hline & Marketing cost & 98.00 & 1.41 & 99.30 & 1.32 \\
\hline & Insecticide cost & 64.96 & 0.94 & 39.06 & 0.52 \\
\hline & Tools and equipment cost & 22.00 & 0.32 & 22.00 & 0.29 \\
\hline & Honey extraction cost & 6.50 & 0.09 & 7.21 & 0.10 \\
\hline \multicolumn{2}{|c|}{ Total variable cost } & 2358.76 & 34.00 & 2637.20 & 35.00 \\
\hline \multirow[t]{4}{*}{ B. } & Hive cost & 382.18 & 5.51 & 834.67 & 11.08 \\
\hline & Colony cost & 3880.00 & 55.93 & 3719.33 & 49.36 \\
\hline & Rent cost & 80.00 & 1.15 & 80.00 & 1.06 \\
\hline & Interest on operating capital & 235.87 & 3.40 & 263.72 & 3.50 \\
\hline \multicolumn{2}{|c|}{ Total Fixed Costs } & 4578.05 & 66.00 & 4897.72 & 65.00 \\
\hline C. & Total cost $(\mathrm{A}+\mathrm{B})$ & 6936.81 & 100.00 & 7534.92 & 100.00 \\
\hline
\end{tabular}

The labour cost for wooden hive is Tk 615.53 per hive which is higher than that of poly hive (499.80). More labour is required for apiary management in wooden hive which might be the reason behind it (Table 1). The feed costs were Tk. 1764.00 and Tk. 1347.73 per hive for poly and wooden hive, respectively. The reason behind higher feed cost in poly hive than that of wooden hive might be the higher requirement of feed for larger colony size and higher amount of honey production. Among the fixed inputs, colony and hive costs were the major contributors. In fact, colony cost was the most crucial cost item for beekeeping. However, colony collection cost for 
poly and wooden hive were Tk. 3719.33 and Tk. 3880.00 per hive, respectively. Better management practice might be the reason behind for lower colony cost of modern poly hive. Another crucial fixed input, beehives were made of woods and plastic. In this study, hive cost was determined by applying straight-line depreciation method in both the production process. However, cost incurred for modern poly hive was almost double than that of wooden hive. High costs of modern poly hive and accessories were responsible for this higher cost.

Table 2. Yearly per hive return of beekeeping.

\section{Comparative return and profitability of beekeeping}

Per hive gross return was calculated by multiplying the total amount of product with respective per unit price and adding the value of by-products. Therefore, the gross return was Tk. 11019.26 per hive of traditional wooden box and Tk. 27373.34 per hive of modern poly hive (Table 2).

\begin{tabular}{|lcccccc|}
\multicolumn{1}{c}{$\begin{array}{c}\text { Return } \\
\text { items }\end{array}$} & Quantity & Price (Tk.) & Return (Tk.) & Quantity & Price (Tk.) & Return (Tk.) \\
\hline Honey & $36.00 \mathrm{~kg}$ & 150.00 & 5400.00 & $57.00 \mathrm{~kg}$ & 200.00 & 11400.00 \\
\hline Wax & $0.39 \mathrm{~kg}$ & 300.00 & 119.26 & $0.78 \mathrm{~kg}$ & 350.00 & 273.34 \\
\hline Pollen & $0.00 \mathrm{~kg}$ & 2000.00 & 0.00 & $0.60 \mathrm{~kg}$ & 2000.00 & 1200.00 \\
\hline Propolis & $0.00 \mathrm{~kg}$ & 1000.00 & 0.00 & $0.60 \mathrm{~kg}$ & 1000.00 & 600.00 \\
\hline Colony & $1.00 \mathrm{nos}$ & 3000.00 & 3000.00 & $3.00 \mathrm{nos}$ & 3000.00 & 9000.00 \\
\hline Queen bee & 5.00 nos & 500.00 & 2500.00 & $7.00 \mathrm{nos}$ & 700.00 & 4900.00 \\
\hline Total & & & 11019.26 & & & 27373.34 \\
\hline
\end{tabular}

Per hive, higher productivity in modern poly hive was the reason for its higher gross return than the beekeeping in traditional wooden hive. Per hive, gross margin and net return of traditional wooden hive were Tk. 8660.50 and Tk. 4082.45,

Table 3. Per hive cost and return of beekeeping.

\begin{tabular}{|c|c|c|c|c|}
\hline $\begin{array}{l}\text { Sl. } \\
\text { No. }\end{array}$ & Items & $\begin{array}{l}\text { Traditional wooden } \\
\text { Amount (Tk.) }\end{array}$ & $\begin{array}{l}\text { Modern poly hive } \\
\text { Amount (Tk.) }\end{array}$ & t-test \\
\hline A. & Gross return & 11019.26 & 27373.34 & \multirow{6}{*}{$0.047^{* *}$} \\
\hline B. & Total variable costs & 2358.76 & 2637.20 & \\
\hline C. & Total costs & 6936.81 & 7534.92 & \\
\hline D. & Gross margin & 8660.50 & 24736.14 & \\
\hline E. & Net return & 4082.45 & 19838.42 & \\
\hline F. & Undiscounted BCR & 1.59 & 3.63 & \\
\hline
\end{tabular}

Note: ** indicates significant at $5 \%$ level.

The benefit cost ratio (BCR) is popularly estimated with the profitability analysis in agricultural economics. This BCR was calculated as the ratio of gross return to total cost (as used by Bala et al., 2020; Sujan et al., 2020 \& 2021). The undiscounted BCR was significantly higher in modern poly hive (3.63) than that of traditional wooden hive (1.59) (Table 3). This statistics reveal the higher profit generating capacity of modern poly hive beekeeping than the traditional wooden hive. These results are also in the line with the findings of Moniruzzaman and Rahman (2009), Islam et al. (2016), Abdullahi et al. (2014) and Al-Ghamdi et al. (2017). respectively, which were Tk. 24736.14 and Tk. 19838.42 for modern poly hive (Table 3 ). The reason for higher gross and net margin of modern poly hive was higher yield with similar production costs. 
significant at one percent level implying good fit of the model. This highly significant F-value implies that all the explanatory variables included in the model were important for explaining the variations in gross return of beekeeping.

The value coefficient for labour, insecticide and equipment cost were 0.077, 0.084 and 0.293 , respectively which were positive and significant at some desired level. The results indicates that remaining other things constant, $10 \%$ increase in the cost for labour, insecticide or equipment lonely would increase the gross return of beekeeping by 0.77 , 0.84 or $2.93 \%$, respectively. The value coefficient for transportation, hive and rent cost were -0.107, -0.128 and -0.115, respectively which were negative and significant at the desired level. These findings implicate that in a ceteris paribus condition, any $10 \%$ increase in the cost for transportation, hive or rent cost lonely would decrease the gross return of beekeeping by $1.07,1.28$ or $1.15 \%$, respectively.

Table 4. Estimated values of coefficients and related statistics of regression analysis.

\begin{tabular}{|lccc|}
\hline Explanatory variables & Coefficient & Standard error & p- value \\
\hline Intercept & 8.441 & 1.57 & 0.00 \\
\hline Labor cost $\left(\mathrm{X}_{1}\right)$ & $0.077^{* *}$ & 0.04 & 0.05 \\
\hline Feed cost $\left(\mathrm{X}_{2}\right)$ & 0.008 & 0.06 & 0.90 \\
\hline Transportation cost $\left(\mathrm{X}_{3}\right)$ & $-0.107^{* *}$ & 0.05 & 0.04 \\
\hline Insecticide cost $\left(\mathrm{X}_{4}\right)$ & $0.084^{*}$ & 0.04 & 0.07 \\
\hline Equipment cost $\left(\mathrm{X}_{5}\right)$ & $0.293^{* *}$ & 0.14 & 0.05 \\
\hline Marketing cost $\left(\mathrm{X}_{6}\right)$ & 0.001 & 0.02 & 0.95 \\
\hline Hive cost $\left(\mathrm{X}_{7}\right)$ & $-0.128^{*}$ & 0.07 & 0.06 \\
\hline Colony cost $\left(\mathrm{X}_{8}\right)$ & 0.112 & 0.12 & 0.37 \\
\hline Rent cost $\left(\mathrm{X}_{9}\right)$ & $-0.115^{*}$ & 0.07 & 0.10 \\
\hline Extraction cost $\left(\mathrm{X}_{10}\right)$ & 0.001 & 0.02 & 0.94 \\
\hline Modern poly hive $(\mathrm{D})$ & $0.317^{* * *}$ & 0.07 & 0.01 \\
\hline $\mathrm{R}^{2}$ & & 0.85 & \\
\hline F-value & & $24.80^{* * *}$ & \\
\hline
\end{tabular}

Note: ${ }^{* * *},{ }^{* *}$ and ${ }^{*}$ indicates significant at 1, 5 and $10 \%$ level, respectively.

In the Cobb-Douglas production function, a dummy variable modern poly hive ( 1 for yes; 0 for no) was also used to examine its special influence on the gross return. The estimated coefficient of the variable was 0.317 , which was significant al $1 \%$ level (Table 4). This result indicates that the gross return for using modern poly hive in beekeeping was $0.317 \%$ higher than that of from the traditional wooden hive.

\section{Resource use efficiency of beekeeping in traditional wooden and modern poly hive}

Resource use efficiency of beekeeping expresses how efficiently the beekeepers used their resources in honey production process. In this study, ten important resources used for honey production i.e. labour, feed, transportation, insecticide, equipment, marketing cost, hive, colony, rental cost, honey extraction cost were analyzed to check the beekeepers resource use efficiency. Results of the study evident that, the ratios of MVP and MFC of labour (1.43), insecticide (15.04), equipment (148.29) and honey extraction (2.69) were greater than unity (Table 5). These findings indicate that, labour, insecticide, equipment and honey extraction cost were under-utilized. Beekeepers could increase the use of those inputs to attain the optimality of the venture.

On the other hand, the ratio of MVP and MFC of feed (0.06), transportation (-4.05), marketing cost (0.02), hive ( -3.01$)$, colony (0.38) and rental cost $(-17.51)$ were less than unity indicating the over-utilization of those resources (Table 5). Beekeepers could reduce the use of those inputs to attain the optimality of honey production. 
Table 5. Resource use efficiency of different inputs in beekeeping.

\begin{tabular}{|lcccccc|} 
Variable & $\begin{array}{c}\text { Geometric } \\
\text { mean }(\mathrm{GM})\end{array}$ & $\begin{array}{c}\text { Co- } \\
\text { efficient }\end{array}$ & MVP $\left(\mathrm{X}_{\mathrm{i}}\right)$ & MFC & RUE & Decision rule \\
\hline Return $\left(\mathrm{Y}_{\mathrm{i}}\right)$ & 11450.41 & 0.077 & & & & \\
\hline Labour $\left(\mathrm{X}_{1}\right)$ & 614.70 & 0.008 & 1.43 & 1 & 1.43 & Under-utilized \\
\hline Feed $\left(\mathrm{X}_{2}\right)$ & 1344.17 & -0.107 & 0.06 & 1 & 0.06 & Over-utilized \\
\hline Transportation $\left(\mathrm{X}_{3}\right)$ & 301.78 & 0.084 & -4.05 & 1 & -4.05 & Over-utilized \\
\hline Insecticide $\left(\mathrm{X}_{4}\right)$ & 63.94 & 0.293 & 15.04 & 1 & 15.04 & Under-utilized \\
\hline Equipment $\left(\mathrm{X}_{5}\right)$ & 22.64 & 0.001 & 148.29 & 1 & 148.29 & Under-utilized \\
\hline Marketing cost $\left(\mathrm{X}_{6}\right)$ & 701.19 & -0.128 & 0.02 & 1 & 0.02 & Over-utilized \\
\hline Hive $\left(\mathrm{X}_{7}\right)$ & 489.26 & 0.112 & -3.01 & 1 & -3.01 & Over-utilized \\
\hline Colony $\left(\mathrm{X}_{8}\right)$ & 3342.88 & -0.115 & 0.38 & 1 & 0.38 & Over-utilized \\
\hline Rental cost $\left(\mathrm{X}_{9}\right)$ & 75.39 & 0.001 & -17.51 & 1 & -17.51 & Over-utilized \\
\hline Honey extraction cost $\left(\mathrm{X}_{10}\right)$ & 6.11 & 0.077 & 2.69 & 1 & 2.69 & Under-utilized \\
\hline
\end{tabular}

\section{Constraints of beekeeping}

In beekeeping, higher costs of modern poly hives and accessories was the primary barriers and $91.7 \%$ of the beekeepers reported about this problem (Table 6). Beekeepers also reported lack of skilled labor (81.67\%), lack of capital (68.33\%), marketing problem (58.33\%), disease, Pest and predator attack (48.33\%), shortage of bee forages (30.00\%), transportation problem (26.67\%), lack of training (21.7\%), death of colony (20.0\%), and poisoning of agro-chemicals (18.3) as the other critical constraints of beekeeping.

Table 6. Constraint faced by the beekeeper.

\begin{tabular}{|clccc|}
\hline $\begin{array}{c}\text { Serial } \\
\text { Number }\end{array}$ & \multicolumn{1}{c}{ Constraint } & Frequency & Percent & Rank \\
\hline 1. & Higher cost of modern hives and accessories & 172 & $91.7 \%$ & $1^{\text {st }}$ \\
\hline 2. & Lack of skilled labor & 156 & $81.7 \%$ & $2^{\text {nd }}$ \\
\hline 3 & Lack of capital & 142 & $68.3 \%$ & $3^{\text {rd }}$ \\
\hline 4. & Marketing problem & 135 & $58.3 \%$ & $4^{\text {th }}$ \\
\hline 5. & Disease, Pest and predator attack & 121 & $48.3 \%$ & $5^{\text {th }}$ \\
\hline 6. & Shortage of bee forages & 112 & $30.0 \%$ & $6^{\text {th }}$ \\
\hline 7. & Transportation problem & 102 & $26.7 \%$ & $7^{\text {th }}$ \\
\hline 8. & Lack of training & 92 & $21.7 \%$ & $8^{\text {th }}$ \\
\hline 9. & Death of colony & 83 & $20.0 \%$ & $9^{\text {th }}$ \\
\hline 10 & Poisoning of agro-chemicals & 66 & $18.3 \%$ & $10^{\text {th }}$ \\
\hline
\end{tabular}

\section{Conclusion}

The study was conducted to estimate the comparative profitability and resource use efficiency of beekeeping using traditional wooden hive and modern poly hive in some selected areas of Bangladesh. Findings of the study reveal that beekeeping in both the traditional and modern poly hive technology was profitable. BCR comparison and significant positive dummy variable 'modern poly hive' imply that beekeeping in modern poly hive was more profitable than the traditional wooden hive. Major inputs i.e. labour, transportation, insecticide, equipment, hive and rental costs significantly influenced the returns of beekeeping. However, labour, insecticide, equipment, and honey extraction inputs were under-utilized while feed, transportation, marketing, hive, colony and rental cost inputs were over-utilized. Beekeepers could increase their resource use efficiency by optimizing the use of those inputs. Based on the findings, beekeeping in modern poly hive is recommended for enhancing profitability and resource use efficiency in beekeeping. Necessary steps from government and other related organizations to mitigate the problems of high costs of modern poly hive accessories, lack of skilled labour and initial capital, inadequate transportation and marketing facilities, will also help to flourish this apiary industry.

\section{Acknowledgement}

This research was carried out by the grant from the National Science and Technology (NST) Fellowship given by the Ministry of Science and Technology of Bangladesh. The authors are grateful to Dr. Asif Reza Anik, Associate Professor, Bangabandhu Sheikh Mujibur Rahman Agricultural University (BSMRAU), Gazipur, for his continuous guidance and support. They also extend their gratitude to the beekeepers and data collectors for their help and cooperation. 


\section{References}

Abdullah, M. 2019. Local and foreign brands race to grab large honey market. Dhaka tribune. $4^{\text {th }} \quad$ March, 2019. Retrieved at https://www.dhakatribune.com/business/2 019/03/04/local-and-foreign-brands-raceto-grab-large-honey-market on $25^{\text {th }}$ April, 2021.

Abdullahi, A., Isekenegbe, J. and Mohammed, U.S. 2014. Comparative economic analysis of modern and traditional bee-keeping in Lere and Zaria Local Government areas of Kaduna State, Nigeria. Int. J. Dev. Sust. 3(5): 989-999.

Adgaba, N., Al-Ghamdi, A., Shenkute, A.G., Ismaiel, S., Al-kahtani, S., Tadess, Y., Ansari, M.J., Abebe, W. and Abdulaziz, M.Q.A. 2014. Socio-economic analysis of beekeeping and determinants of box hive technology adoption in the Kingdom of Saudi Arabia. $J$. Anim. Plant Sci. 24(6): 1876-1884.

Al-Ghamdi, A.A., Adgaba, N., Herab, A.H. and Ansari, M.J. 2017. Comparative analysis of profitability of honey production using traditional and box hives. Saudi J. Biol. Sci. 24: 1075-1080.

https://doi.org/10.1016/j.sjbs.2017.01.007

Ayansola, A.A. and Davies, B.A. 2012. Honeybee floral resources in southwestern Nigeria. $J$. Biol. Life Sci. 3(1): 127-139.

https://doi.org/10.5296/jbls.v3i1.1720

Bala, H., Ghosh, A.K., Kazal, M.M.H., Rahman, M.S., Sultana, M. and Sujan, M.H.K. 2020. Floating gardening in Bangladesh: a sustainable income generating activity in wetland areas. Int. J. Agril. Res. Innov. Tech. 10(1): 87-93.

https://doi.org/10.3329/ijarit.v10i1.48098

Beattie, B.R. and Taylor, C.R. 1985. The Economics of Production. Montana State University, John Wiley and Sons, New York, USA. pp. 179-222.

Famuyide, O.O., Adebayo, O., Owese, T., Azeez, F.A., Arabomen, O., Olugbire, O.O. and Ojo, D. 2014. Economic contributions of honey production as a means of livelihood strategy in Oyo state. Int. J. Sci. Tech. 3(1): 7-9.

Fazlullah, M.M.U. 2018. A study on honey production by using wooden and poly hive in different seasons in Bangladesh. MS Thesis, Department of Entomology. Sher-e-Bangla Agricultural University, Dhaka.

Getachew, A., Assefa, A., Gizaw, H., Adgaba, N., Assefa, D., Tajebe, Z. and Tera, A. 2015. Comparative analysis of colony performance and profit from different beehive types in southwest Ethiopia. Global J. Anim. Sci. Res. 3(1): 178-185.

Hossain, M.S. 2017. Beekeeping in Bangladesh, In: Kozmus P. et al. (1 $1^{\text {st }}$ ed.), No Bees, No Life, Beebooks d.o.o. Zirovnica, Slovenia. pp. 220-226.

Hossain, M.S., Fazlullah, M.M.U. and Rahman, M.M. 2019. Comparative Performance of honey production from two different bee hives in Bangladesh. The Agriculturists. 17(1-2): 102-111.

https://doi.org/10.3329/agric.v17i1-2.44700 Islam, M.R., Chhay, L., Mian, M.M. and Nasry, A.A.N.B. 2016. The financial analysis of apiculture profitability in Bangladesh. Asian J. Agril. Ext. Econ. Soc. 9:(2): 1-8.

https://doi.org/10.9734/AJAEES/2016/22985

Kiros, W. and Tsegay, T. 2017. Honey-bee production practices and hive technology preferences in Jimma and Illubabor zone of Oromiya regional state, Ethiopia. Acta Univ. Sapien. Agric. Environ. 9: 31-43.

https://doi.org/10.1515/ausae-2017-0003

Klatt, B.K., Holzschuh, A., Westphal, C., Clough, Y., Smit, I., Pawelzik, E. and Tscharntke, T. 2014. Bee pollination improves crop quality, shelf life and commercial value. Proc. R. Soc. B. 281(1775): 20132440.

https://doi.org/10.1098/rspb.2013.2440

Kumsa, T. and Takele, D. 2014. Assessment of the effect of seasonal honeybee management on honey production of Ethiopian honeybee (Apis mellifera) in modern beekeeping in Jimma Zone. Res. J. Agric. Environ. Manage. 3(5): 246-254.

https://doi.org/10.15580/GJPBCS.2014.3.010314013

Moniruzzaman, M. and Rahman, M.S. 2009. Prospects of beekeeping in Bangladesh. $J$. Bangladesh Agril. Univ. 7(1): 109-116. https://doi.org/10.3329/jbau.v7i1.4972

Sujan, H.K., Islam, F., Kazal, M.H. and Mondal, R.K. 2017a. Profitability and resource use efficiency of potato cultivation in Munshiganj district of Bangladesh. SAARC J. Agric. 15(2): 193-206.

https://doi.org/10.3329/sja.v15i2.35151

Sujan, M.H.K., Ghosh, A.K., Sultana, M., Islam, F. and Sadia, F.T. 2020. Economics of shifting land from field crops to hog plum (Spondias mombin L.) cultivation in southern Bangladesh. Int. J. Agril. Res. Innov. Tech. 10(2): 155-163.

https://doi.org/10.3329/ijarit.v10i2.51589

Sujan, M.H.K., Islam, F., Azad, M.J. and Rayhan, S.J. 2017b. Financial profitability and resource use efficiency of boro rice cultivation in some selected area of Bangladesh. African J. Agric. Res. 12(29): 2404-2411.

https://doi.org/10.5897/AJAR2017.12443

Sujan, M.H.K., Kazal, M.M.H., Ali, M.S. and Rahman, M.S. 2021. Cost-benefit analysis of mud crab fattening in coastal areas of Bangladesh. Aqua. Rep. 19: 100612. https://doi.org/10.1016/j.aqrep.2021.100612

Vaziritabar, S. and Esmaeilzade, S.M. 2016. Profitability and socio-economic analysis of beekeeping and honey production in Karaj state, Iran. J. Entomol. Zool. Stud. 4(4): 1341-1350.

Veer, S. and Jitender, N. 2017. Economics and Importance of Beekeeping. Biomed J. Sci Tech. Res. 1(7): 1833-1834.

https://doi.org/10.26717/BJSTR.2017.01.000561 